\title{
Randomly amplified polymorphic DNA (RAPD) analysis of Atlantic Coast striped bass
}

\author{
JOSEPH P. BIELAWSKI* $† \&$ DOROTHY E. PUMO \\ Department of Biology, 114 Hofstra University, Hempstead, New York 11550, U.S.A.
}

\begin{abstract}
Atlantic Coast striped bass exhibit exceptionally low levels of genetic variation. The ability of the randomly amplified polymorphic DNA (RAPD) method to uncover genetic variation in this highly conserved species was investigated. Sufficient levels of variation were detected to allow a population genetic analysis of the four migratory populations of Atlantic Coast striped bass. Lynch's analogue of Wright's $F_{\mathrm{ST}}\left(F_{\mathrm{ST}}^{\prime}\right)$ suggests that Atlantic Coast striped bass are genetically subdivided $\left(F_{\text {ST }}^{\prime}\right.$ for pooled Atlantic samples $\left.=0.44\right)$. Significant heterogeneity was detected in the frequencies of 32 per cent of surveyed RAPD markers. A modification of Slatkin's conditional average frequency method suggests that gene flow is present among the sampled Atlantic Coast striped bass. Results of the RAPD analysis suggest that gene flow is sufficient to prevent fixation of alternate genetic markers, but not sufficient to prevent the development of significant divergence in frequencies of these markers.
\end{abstract}

Keywords: genetic variation, Morone, population genetics, RAPD, striped bass.

\section{Introduction}

Striped bass (Morone saxatilis) are endemic to the Atlantic Coast of North America and the northern Gulf of Mexico. Striped bass are anadromous, with individuals moving from marine to fresh waters of coastal tributaries for purposes of spawning. Most natural populations of striped bass are riverine in nature. However, striped bass originating from Hudson River, Delaware River, Chesapeake Bay, and Roanoke River drainage systems have historically undertaken extensive coastal migrations (Merriman, 1941). Striped bass of these river systems become mixed during this migration and form an important mixed-stock fishery responsible for revenue in the millions of dollars (Koo, 1970). Seasonal migration begins in the spring and movement is generally northward along the Atlantic coast. Striped bass return south along the coast in fall to overwinter within the proximity of their natal river systems. Tagging studies indicate that migratory striped bass return to their natal tributaries to spawn (reviewed in Setzler et al., 1980; Rago et al., 1992).

\section{${ }^{*}$ Correspondence.}

†Current address: Department of Wildlife and Fisheries Sciences, Texas A\&M University, College Station, Texas 77843-2258, U.S.A. E-mail: j-bielawski@tamu.edu
The combination of increasing fishing pressure and degradation of important estuarine nursery habitat ultimately resulted in an almost complete crash of the Mid-Atlantic striped bass fishery in the 1980s (Boreman \& Austin, 1985; Rago et al., 1992). Following this collapse, strict regulatory measures were imposed which effected a complete halt of fishing pressure on the striped bass of the Mid-Atlantic region (Rago et al., 1992). Today, numbers of striped bass have returned to levels approaching historic highs making striped bass one of the biggest success stories in the field of fisheries conservation.

A major issue in the management of Mid-Atlantic striped bass populations is identification and characterization of genetically distinct populations. Reproductive fidelity of migrating striped bass for their natal tributary suggests reproductive isolation exists between river systems. Over the last 30 years much attention has been devoted to detecting genetic markers that would allow characterization of these presumably isolated populations (reviewed by Waldman et al., 1988; Wirgin et al., 1990; Waldman \& Wirgin, 1993). Numerous population genetic studies of striped bass nuclear loci revealed exceptionally low levels of genetic variation making characterization of their population genetics with these methods seemingly impossible (reviewed by Waldman et al., 1988). Analysis of striped bass mito- 
chondrial DNA (mtDNA) suggests that subdivision exists among some populations of migratory striped bass (Wirgin et al., 1990).

Extensive male-based gene flow between tributaries within the Chesapeake Bay is thought to account for the observed nuclear gene homogeneity of these populations (Chapman, 1987, 1989). Yet, because of strong reproductive fidelity of female striped bass for their natal tributaries and maternal inheritance of the mtDNA genome, significant divergence of mtDNA markers has occurred among tributaries of the Chesapeake Bay (Chapman, 1990; Wirgin et al., 1990). Therefore, it is important that a sensitive method of detecting nuclear DNA variation be applied to the analysis of migratory stocks of Atlantic Coast striped bass in order to determine if the nuclear genome exhibits the same pattern of divergence indicated by mtDNA analyses.

The purpose of this study was to employ the RAPD method (Williams et al., 1990) to (i) uncover sufficient nuclear DNA variation to conduct a population genetic analysis of migratory striped bass, and (ii) identify sets of genetic markers suitable for

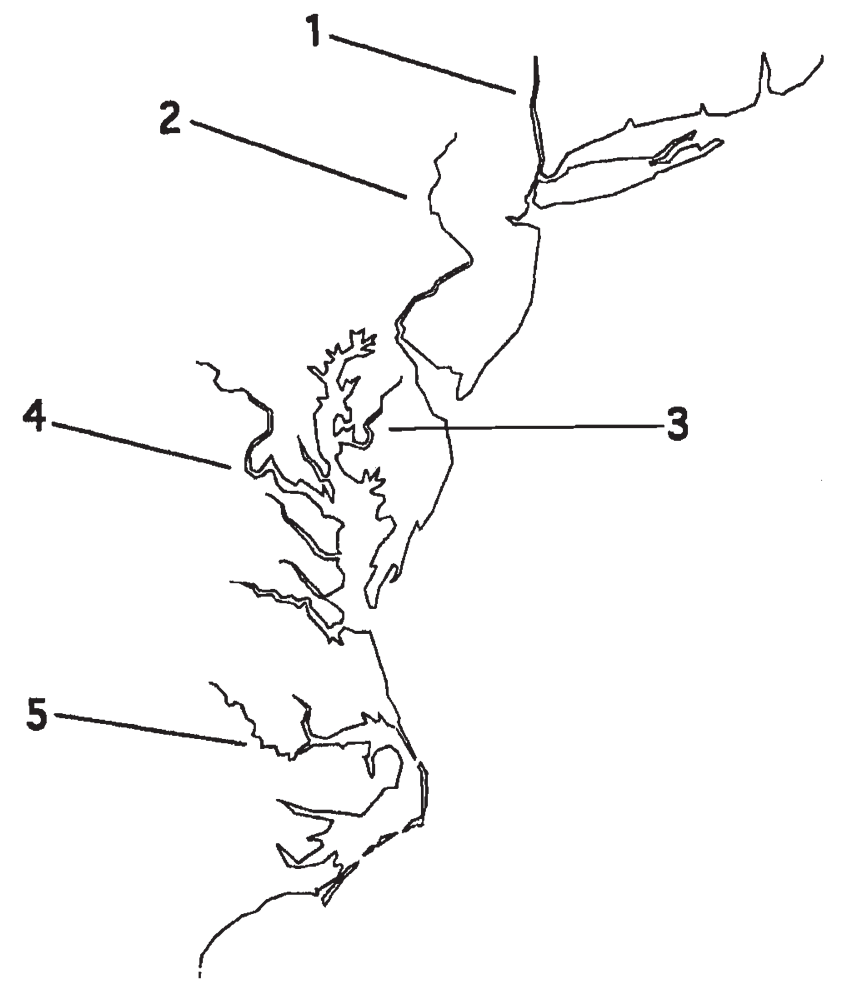

Fig. 1 Sample localities for striped bass, Morone saxatilis, examined in this study. Samples were as follows: 1, Hudson River $(n=29)$; 2, Delaware River $(n=26)$; 3 , Potomac River $(n=12)$; 4, Choptank River $(n=19)$; and 5 , Roanoke River $(n=28)$. Collection of the samples is described in the text. resolving stock composition of the migratory mixedstock fishery. The RAPD method was employed because it is an extremely sensitive method of detecting nuclear DNA variation. Given the inability of other more traditional methods of analysis to reveal sufficient levels of nuclear DNA variation in striped bass, a test of the RAPD method for a population analysis of striped bass was warranted.

\section{Materials and methods}

\section{Sample collection, DNA extraction, amplification, and electrophoresis}

Striped bass were collected in 1992 from the Hudson River $(n=29)$, Delaware River $(n=26)$, Choptank $(n=19)$ and Potomac Rivers $(n=12)$ of the Chesapeake Bay, and Roanoke River $(n=28)$ (Fig. 1). Young of the year specimens were collected, ensuring that each sample reflected reproduction that occurred within the sampled river system. The striped bass were frozen as soon after capture as possible. Skeletal muscle tissue was digested using Proteinase K, and genomic DNA was isolated using phenol:chloroform extraction and ethanol precipitation (Sambrook et al., 1989). Optimization of PCR chemical reaction conditions and amplification profile is described in Bielawski et al. (1995). After completion of the cycling programme, PCR products were resolved using agarose gel (1.4 per cent) electrophoresis.

A negative control reaction was prepared for each primer employed in all PCR amplifications to identify contamination of reactions with nontarget template DNA. Furthermore, amplification of multiple template DNA concentrations of every sample was carried out for all primers surveyed as a means of identifying artifactual variation (Bielawski et al., 1995).

\section{Primer selection}

Two kits (designated $\mathrm{C}$ and $\mathrm{K}$ ), each containing 20 decamer primers of random sequence, were obtained from Operon Technologies, Alameda, CA (Table 1). Genomic DNA of two individuals from each drainage-system sample (Hudson River, Delaware River, Chesapeake Bay, and Roanoke River) were used as templates for amplification of RAPD markers with each of the 40 decamer primers. Amplification was performed on three concentrations of each sample of template DNA. Primers were evaluated based on intensity of bands, consistency within individuals, presence of smearing, and 
Table 1 Summary of the number and characteristics of amplification products obtained from a survey of forty decamer primers of random sequence

\begin{tabular}{|c|c|c|c|c|c|}
\hline Primer & $5^{\prime}$-sequence- $3^{\prime}$ & Scorable & Polymorphic & No. bands & Size range \\
\hline OPC-01 & TTCGAGCCAG & $\mathrm{Y}$ & $\mathrm{N}$ & 6 & $320-1800$ \\
\hline OPC-02 & GTGAGGCGTC & $\mathrm{Y}$ & $\mathrm{Y}$ & 12 & $340-1050$ \\
\hline OPC-03 & GGGGGTCTTT & $\mathrm{N}^{*}$ & - & - & - \\
\hline OPC-04 & CCGCATCTAC & $\mathrm{Y}$ & $\mathrm{N}$ & 12 & $330-2200$ \\
\hline OPC-05 & GATGACCGCC & $\mathrm{Y}$ & $\mathrm{N}$ & 13 & $280-2000$ \\
\hline OPC-06 & GAACGGACTC & $\mathrm{Y}$ & $\mathrm{N}$ & 7 & $400-1800$ \\
\hline OPC-07 & GTCCCGACGA & $\mathrm{N}^{*}$ & - & 9 & $270-1750$ \\
\hline OPC-08 & TGGACCGGTG & $\mathrm{Y}$ & $\mathrm{N}$ & 9 & $700-1700$ \\
\hline OPC-09 & CTCACCGTCC & $\mathrm{Y}$ & $\mathrm{N}$ & 10 & $650-3500$ \\
\hline OPC-10 & TGTCTGGGTG & $\mathrm{Y}$ & $\mathrm{N}$ & 6 & $340-2200$ \\
\hline OPC-11 & AAAGCTGCGG & $\mathrm{Y}$ & $Y \ddagger$ & 13 & $200-1900$ \\
\hline OPC-12 & TGTCATCCCC & $\mathrm{Y}$ & $\mathrm{N}$ & 8 & $550-1800$ \\
\hline OPC-13 & AAGCCTCGTC & $\mathrm{Y}$ & $\mathrm{Y}$ & 9 & $310-2300$ \\
\hline OPC-14 & TGCGTGCTTG & $\mathrm{Y}$ & $\mathrm{N}$ & 8 & $400-2200$ \\
\hline OPC-15 & GACGGATCAG & $\mathrm{N} \dagger$ & - & 6 & $240-1600$ \\
\hline OPC-16 & CACACTCCAG & $\mathrm{Y}$ & $\mathrm{N}$ & 5 & $600-2500$ \\
\hline OPC-17 & TTCCCCCCAG & $\mathrm{Y}$ & $\mathrm{N}$ & 7 & $300-2500$ \\
\hline OPC-18 & TGAGTGGGTG & $\mathrm{Y}$ & $Y$ & 9 & $500-2300$ \\
\hline OPC-19 & GTTGCCAGCC & $\mathrm{Y}$ & $\mathrm{N}$ & 8 & $750-1650$ \\
\hline OPC-20 & ACTTCGCCAC & $\mathrm{Y}$ & $\mathrm{N}$ & 10 & $380-1800$ \\
\hline OPK-01 & CATTCGAGCC & $\mathrm{Y}$ & $\mathrm{Y}$ & 16 & $290-2050$ \\
\hline OPK-02 & GTCTCCGCAA & $\mathrm{Y}$ & $\mathrm{Y}$ & 5 & $380-0675$ \\
\hline OPK-03 & CCAGCTTAGG & $\mathrm{Y}$ & $\mathrm{N}$ & 6 & $450-2600$ \\
\hline OPK-04 & CCGCCCAAAC & $\mathrm{Y}$ & $\mathrm{N}$ & 9 & $360-2300$ \\
\hline OPK-05 & TCTGTCGAGG & $\mathbf{N}^{*}$ & - & - & - \\
\hline OPK-06 & САССТТТССС & $\mathrm{Y}$ & $\mathbf{N}$ & 9 & $330-2100$ \\
\hline OPK-07 & AGCGAGCAAG & $\mathrm{N} \dagger$ & - & - & - \\
\hline OPK-08 & GAACACTGGG & $\mathrm{Y}$ & $\mathrm{N}$ & 7 & $600-3500$ \\
\hline OPK-09 & CCCTACCGAC & $\mathrm{Y}$ & - & - & - \\
\hline OPK-10 & GTGCAACGTG & $\mathrm{N}^{*}$ & - & 9 & $390-2000$ \\
\hline OPK-11 & AATGCCCCAG & $\mathrm{Y}$ & $\mathbf{N}$ & 8 & $410-2900$ \\
\hline OPK-12 & TGGCCCTCAC & $\mathrm{Y}$ & $\mathrm{N}$ & 8 & $600-1500$ \\
\hline OPK-13 & GGTTGTACCC & $\mathrm{Y}$ & - & - & - \\
\hline OPK-14 & CCCGCTACAC & $\mathrm{Y}$ & $\mathrm{Y}$ & 11 & $320-1500$ \\
\hline OPK-15 & CTCCTGCCAA & $\mathrm{Y}$ & $\mathbf{N}$ & 12 & $280-2400$ \\
\hline OPK-16 & GAGCGTCGAA & $\mathrm{N} \dagger$ & - & - & - \\
\hline OPK-17 & CCCAGCTGTG & $\mathrm{Y}$ & $\mathrm{N}$ & 12 & $270-2100$ \\
\hline OPK-18 & CCTAGTCGAG & $\mathrm{Y}$ & $\mathrm{N} \ddagger$ & - & - \\
\hline OPK-19 & CACAGGCGGA & Y & $\mathrm{Y}$ & 11 & $160-1300$ \\
\hline OPK-20 & GTGTCGCGAG & $\mathrm{Y}$ & $\mathrm{Y}$ & 10 & $230-0780$ \\
\hline
\end{tabular}

${ }^{*}$ Highly smeary and/or inconsistent amplification products.

$\dagger$ No amplification products.

$\ddagger$ Inconsistent amplification of only certain products.

potential for population discrimination. The most important criterion for primer selection was consistency of amplification across a 100-fold span of DNA concentrations. Primers exhibiting the highest quality banding patterns and sufficient variability for population analysis were selected for amplification with two additional individuals from each drainage system. A final subset of primers was then selected for population analysis.

\section{Population analysis}

Genomic DNA samples of individual striped bass from each drainage system were surveyed for RAPD 
markers using the primers selected in the above primer survey. Amplification of a minimum of two concentrations of every sample of template DNA was carried out for all primers surveyed. Amplification products from different concentrations of template DNA were compared to identify artifactual variation. Amplification products exhibiting artifactual variation were dropped from the analysis. The lengths in base pairs of the amplified sequences of DNA were estimated by comparison to a molecular standard and named according to the convention suggested by Paran et al. (1991).

Frequencies of the polymorphic RAPD markers were determined for each population sample. Testing for significant differences in marker frequencies was accomplished using $G$-tests (Sokal \& Rohlf, 1969) of contingency tables of marker counts. The $G$-tests were carried out using the віом-PC program package (Rohlf, 1983). The sequential Bonferroni method was used to compute table-wide significance levels to control for the probability of incorrectly rejecting one or more component null hypotheses (Rice, 1989).

Mean bandsharing similarity indices between individuals within a population sample $\left(S_{i}\right)$ and between population samples $\left(S_{i j}\right)$ were computed for all possible comparisons according to the method of Lynch (1991). Lynch's (1991) analogue of Wright's $F_{\mathrm{ST}}\left(F^{\prime}{ }_{\mathrm{ST}}\right)$ was computed for the total data set and between geographically proximate population samples using a measure of interpopulation bandsharing corrected for within-population variation.

Distance measures were computed from both frequency and bandsharing data. Nei's (1978) unbiased genetic distance values were computed from frequencies of polymorphic markers using the BIOSYS-1 computer package (Swofford \& Selander, 1981). Lynch's (1991) analogue of Nei's unbiased genetic distance $\left(D^{\prime}{ }_{i j}\right)$ was computed manually from mean similarity within- $\left(S_{i}\right)$ and between-population $\left(S_{i j}\right)$ samples. Cluster analysis of both sets of distance measures via UPGMA (Unweighted Pair Group Method of Arithmetic means) was carried out using a computer program written by Dr N. Saitou of the University of Texas Science Center at Houston. This program also determines the standard error for each node of the dendrogram according to the method of Nei et al. (1985).

Maximum and minimum qualitative estimates of gene flow were determined using a modification of Slatkin's (1981) method. Because dominance can yield an underestimate of the frequencies of rare null markers (Clark \& Lanigan, 1993), conditional average marker frequencies $[p(i)]$ computed using null markers will provide an upper-bound or maximum qualitative estimate of gene flow. A minimum qualitative estimate can be obtained by overestimating rare marker frequencies. Minimum qualitative estimates of gene flow were determined by ignoring null markers and treating all rare dominant markers as homozygous.

\section{Results}

An evaluation of 40 different decamer primers was conducted with representatives of the four sampling localities (Table 1). Thirty-three primers (82.5 per cent) produced high intensity amplification products with minimal smearing. However, two of these primers (OPC-11 and OPK-18) produced highly inconsistent amplification products across different DNA concentrations from the same individual and were dropped from further analysis. Twenty-four primers ( 74 per cent of the scorable primers) produced completely monomorphic amplification products. The eight primers that produced polymorphic products (Table 1) were evaluated with two additional representatives from each sampling locality. Primers OPC-2, OPK-1, OPK-2, OPK-19 and OPK-20 were selected based on the quality of their amplification products for the population analysis.

Striped bass from each collection locality were surveyed for polymorphic markers with each of the above primers. A total of 53 amplification products were identified with 33 polymorphisms detected. A single amplification product was dropped from the analysis because spurious amplification was detected across DNA template concentrations. A second marker (OPK-2650) was dropped from analysis because it displayed identical frequencies to another marker produced from the same primer (OPK-2 675$)$ in all four population samples. This strongly suggested nonindependence, probably the result of linkage of the two markers. Frequencies of polymorphic RAPD markers are presented in Table 2. Only a single population-specific marker (OPC-2 360$)$ was detected. This marker was found at a frequency of 0.19 in the Delaware River sample and was absent from all other samples. Overall, 26 of the polymorphic markers were present in all four of the samples.

$G$-statistics from contingency-table analysis of RAPD marker frequencies are presented in Table 3. Sixteen of 31 markers ( 52 per cent) showed significant heterogeneity using the single-test significance level of 0.05 (Table 3). Using the sequential Bonferroni method, 10 markers ( 32 per cent) showed significant heterogeneity at table-wide significance levels 
Table 5 Summary of Nei's (1978) unbiased genetic distance values based on RAPD marker frequencies (upper diagonal) and Lynch's (1991) analogue of Nei's unbiased genetic distance $\left(D_{i j}^{\prime}\right)$ based on bandsharing similarity indices (lower diagonal) among striped bass sampled from the Hudson River, Delaware River, Chesapeake Bay and Roanoke River

\begin{tabular}{lcccc}
\hline & 1 & 2 & 3 & 4 \\
\hline 1. Hudson River & - & 0.036 & 0.100 & 0.042 \\
2. Delaware River & 0.051 & - & 0.081 & 0.038 \\
3. Chesapeake Bay & 0.072 & 0.070 & - & 0.074 \\
4. Roanoke River & 0.053 & 0.052 & 0.062 & - \\
\hline
\end{tabular}
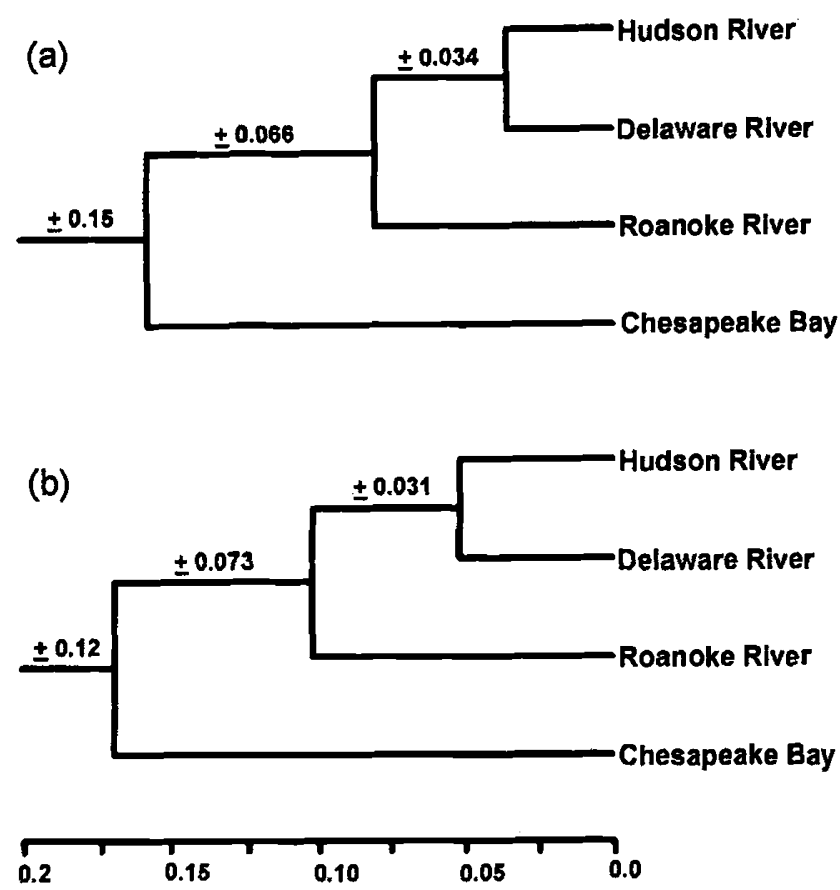

Fig. 2 UPGMA dendrograms for striped bass based on (a) Nei's (1978) unbiased genetic distance computed from RAPD marker frequencies, and (b) Lynch's (1991) analogue of Nei's unbiased genetic distance computed from bandsharing similarity indices.

Analyses of frequencies of RAPD markers and bandsharing indices suggest genetic subdivision. Using sequential Bonferroni table-wide $P$-values, significant heterogeneity among the four sampled drainage systems was detected in the frequencies of 32 per cent of the polymorphic RAPD markers. Significant levels of divergence in frequencies of shared markers assumed to be independent and selectively neutral indicate a genome-wide effect resulting from a restriction in gene flow (Wright,

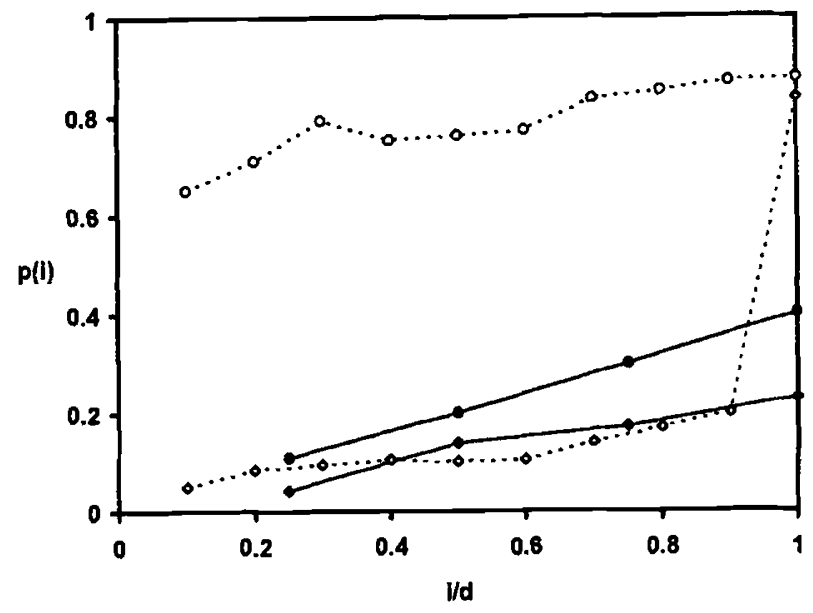

.. Slatkin's (1981) theoretical profile for a high gene flow species.

.....Slatkin's (1981) theoretical proflle for a low gene flow species.

-Maximum profile for striped bass gene flow.

$\rightarrow$ - Minimum profile for striped bass gene flow.

Fig. 3 Maximum and minimum qualitative estimates of gene flow for the striped bass. Profiles were obtained by plotting conditional-average RAPD marker frequencies $[p(i)]$ verses occupancy rate $(i / d)$. Theoretical profiles for high gene flow $\left(N_{\mathrm{e}} m=1.250\right)$ and low gene flow $\left(N_{\mathrm{e}} m=0.025\right)$ are after Slatkin (1981).

1969). Bandsharing-based similarity indices are higher for within-river system samples than for all comparisons between river systems (Table 4). This implies that individuals within each river system are genetically more similar to each other than to individuals from any other river system. Estimates of $F^{\prime}{ }_{\text {ST }}$ using these bandsharing similarity values indicate the presence of subdivision among river system samples $\left(F_{\mathrm{ST}}^{\prime}=0.44\right)$. Because subdivision was detected in the pooled Atlantic Coast samples, $F^{\prime}{ }_{\text {ST }}$ was computed stepwise between geographically proximate river systems and genetic subdivision was indicated in all comparisons (Table 4). Collectively, these data suggest that striped bass of the Hudson River, Delaware River, Chesapeake Bay, and Roanoke River systems are genetically differentiated from each other.

In general, results of both mitochondrial (Wirgin et al., 1990) and RAPD analyses are concordant in suggesting divergence among Atlantic Coast striped bass. However, the RAPD analysis suggests that genetic differentiation exists between Hudson River and Roanoke River striped bass $\left(F^{\prime}{ }_{S T}=0.46\right)$ that was not detected by previous mtDNA analysis (Wirgin et al., 1990). It is not unexpected that the RAPD analysis suggests divergence between these populations given that these two river systems are 
Table 3 Results of $G$-tests for heterogeneity in RAPD marker frequencies among striped bass sampled from the Hudson River, Delaware River, Chesapeake Bay and Roanoke River

\begin{tabular}{|c|c|c|}
\hline RAPD marker & $G$-score & $P$-value \\
\hline OPC $-2_{1025}$ & 5.371 & $>0.05$ \\
\hline OPC -2 & 0.282 & $>0.05$ \\
\hline OPC- $2_{700}$ & 12.040 & ${ }^{*}<0.01$ \\
\hline OPC- $2_{500}$ & 6.176 & $>0.05$ \\
\hline OPC- $2_{490}$ & 10.789 & $*<0.05$ \\
\hline OPC -2420 & 36.429 & $t^{*}<0.001$ \\
\hline OPC $-2_{410}$ & 4.580 & $>0.05$ \\
\hline OPC- $2_{360}$ & 15.407 & $\dagger^{*}<0.01$ \\
\hline OPK-1 $1_{1600}$ & 10.426 & $*<0.05$ \\
\hline OPK-1 $1_{1300}$ & 3.480 & $>0.05$ \\
\hline OPK-1 $1_{850}$ & 5.014 & $>0.05$ \\
\hline OPK- $1_{650}$ & 5.583 & $>0.05$ \\
\hline OPK- $1_{500}$ & 19.122 & $\dagger^{*}<0.001$ \\
\hline OPK-1 1465 & 2.782 & $>0.05$ \\
\hline OPK- $2_{675}$ & 7.558 & $>0.05$ \\
\hline OPK- $2_{380}$ & 4.474 & $>0.05$ \\
\hline OPK- $19_{1300}$ & 2.782 & $>0.05$ \\
\hline OPK-19900 & 4.028 & $>0.05$ \\
\hline OPK-19 $9_{700}$ & 8.725 & $*<0.05$ \\
\hline OPK-19 & 20.562 & $t^{*}<0.001$ \\
\hline OPK-19 $19_{525}$ & 15.904 & $t^{*}<0.01$ \\
\hline OPK $-19_{280}$ & 16.411 & $t^{*}<0.001$ \\
\hline OPK $-20_{780}$ & 23.096 & $t^{*}<0.001$ \\
\hline OPK-20 $0_{750}$ & 10.068 & $*<0.01$ \\
\hline OPK- $20_{725}$ & 2.447 & $>0.05$ \\
\hline OPK $-20_{700}$ & 2.840 & $>0.05$ \\
\hline OPK-20 205 & 21.056 & $t^{*}<0.001$ \\
\hline OPK-20 500 & 15.084 & $*<0.01$ \\
\hline OPK- $20_{350}$ & 2.689 & $>0.05$ \\
\hline OPK- $20_{280}$ & 20.797 & $t^{*}<0.001$ \\
\hline OPK- $20_{230}$ & 21.073 & $\dagger^{*}<0.001$ \\
\hline
\end{tabular}

Degrees of freedom for $G$-test $=3$.

*Indicates a single-test significant result $(\alpha=0.05)$.

tIndicates a table-wide significant result using the sequential Bonferroni method $(\alpha=0.05)$.

average RAPD marker frequencies produced profiles which closely parallel Slatkin's (1981) theoretical estimate for a high gene flow species (Fig. 3).

\section{Discussion}

\section{Characterization of Atlantic Coast striped bass populations}

Traditional measures of nuclear DNA variation, including isoelectric focusing, allozyme, and isozyme analyses, have detected virtually no genetic variation among Atlantic Coast striped bass (reviewed by
Table 4 Summary of bandsharing-based similarity indices within and between the sampled Atlantic Coast striped bass and estimates of population subdivision based on Lynch's (1991) analogue of Wright's $F_{\mathrm{ST}}\left(F^{\prime}{ }_{\mathrm{ST}}\right)$ computed from these similarity indices

Similarity $\left(S_{i}\right)$ between individuals of the same population

\begin{tabular}{ll} 
Hudson River & $93.0 \%$ \\
Delaware River & $92.6 \%$ \\
Chesapeake Bay & $93.9 \%$ \\
Roanoke River & $95.6 \%$ \\
Average & $93.8 \%$ \\
\hline
\end{tabular}

Similarity $\left(S_{i j}\right)$ between individuals of different populations

Hudson-Delaware $\quad 88.2 \%$

Hudson-Chesapeake $\quad 87.0 \%$

Hudson-Roanoke $\quad 89.4 \%$

Chesapeake-Delaware $\quad 87.8 \%$

Chesapeake-Roanoke $\quad 89.0 \%$

Delaware-Roanoke $\quad 89.2 \%$

Average $88.4 \%$

Estimates of population subdivision $\left(F^{\prime}{ }^{\prime}\right.$ s $)$ computed for pooled Atlantic Coast striped bass samples and stepwise between geographically proximate drainage systems

\begin{tabular}{ll}
\hline Test group & $F^{\prime}{ }_{\text {ST }}$ \\
Atlantic Coast & 0.44 \\
Hudson River and Delaware River & 0.39 \\
Delaware River and Chesapeake Bay & 0.44 \\
Chesapeake Bay and Roanoke River & 0.52 \\
\hline
\end{tabular}

Waldman et al., 1988). Alternatively, the RAPD method uncovered 31 reliable polymorphisms from the five primers selected for population analysis. In contrast to previous studies, the RAPD method revealed sufficient nuclear variation to conduct a population genetic study of Atlantic Coast striped bass. However, the majority of the scorable primers surveyed (75 per cent) produced completely monomorphic banding patterns. Furthermore, similarity indices within samples, calculated from the primers which produced the greatest amount of variation, were between 92 per cent and 96 per cent (Table 4). If similarity indices had been calculated from amplification products of all primers, the values would have been considerably higher. The results of this RAPD analysis not only demonstrate that nuclear DNA variation in Atlantic Coast striped bass is extremely low, but that the RAPD method is capable of revealing nuclear DNA variation in an extremely conserved species. 
Table 5 Summary of Nei's (1978) unbiased genetic distance values based on RAPD marker frequencies (upper diagonal) and Lynch's (1991) analogue of Nei's unbiased genetic distance $\left(D_{i j}^{\prime}\right)$ based on bandsharing similarity indices (lower diagonal) among striped bass sampled from the Hudson River, Delaware River, Chesapeake Bay and Roanoke River

\begin{tabular}{lcccc}
\hline & 1 & 2 & 3 & 4 \\
\hline 1. Hudson River & - & 0.036 & 0.100 & 0.042 \\
2. Delaware River & 0.051 & - & 0.081 & 0.038 \\
3. Chesapeake Bay & 0.072 & 0.070 & - & 0.074 \\
4. Roanoke River & 0.053 & 0.052 & 0.062 & - \\
\hline
\end{tabular}
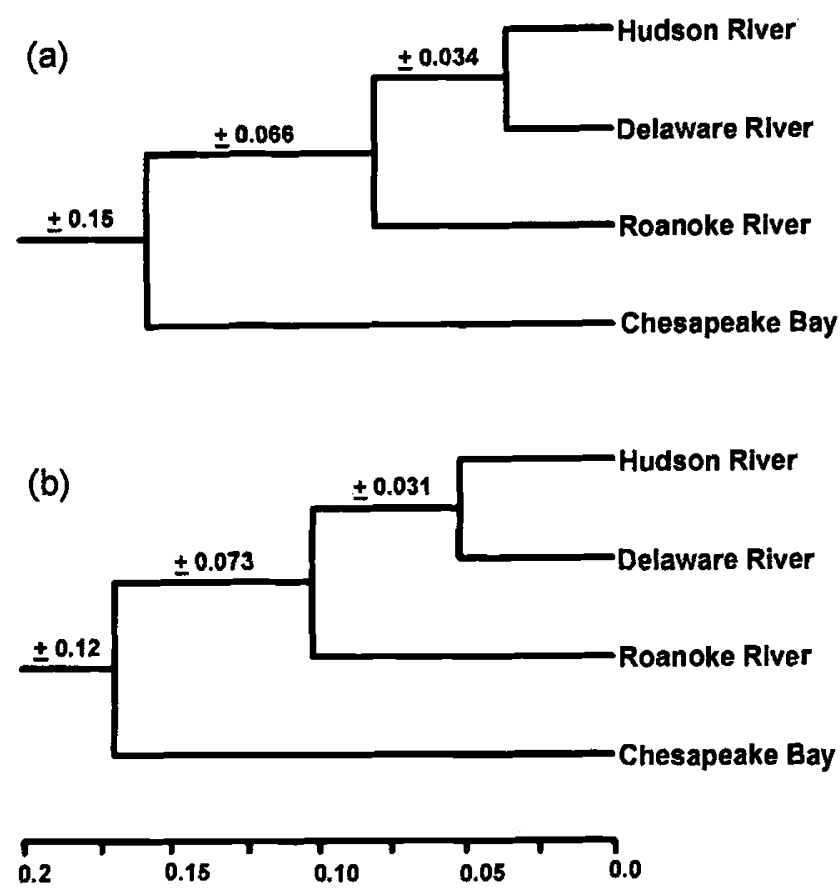

Fig. 2 UPGMA dendrograms for striped bass based on (a) Nei's (1978) unbiased genetic distance computed from RAPD marker frequencies, and (b) Lynch's (1991) analogue of Nei's unbiased genetic distance computed from bandsharing similarity indices.

Analyses of frequencies of RAPD markers and bandsharing indices suggest genetic subdivision. Using sequential Bonferroni table-wide $P$-values, significant heterogeneity among the four sampled drainage systems was detected in the frequencies of 32 per cent of the polymorphic RAPD markers. Significant levels of divergence in frequencies of shared markers assumed to be independent and selectively neutral indicate a genome-wide effect resulting from a restriction in gene flow (Wright,

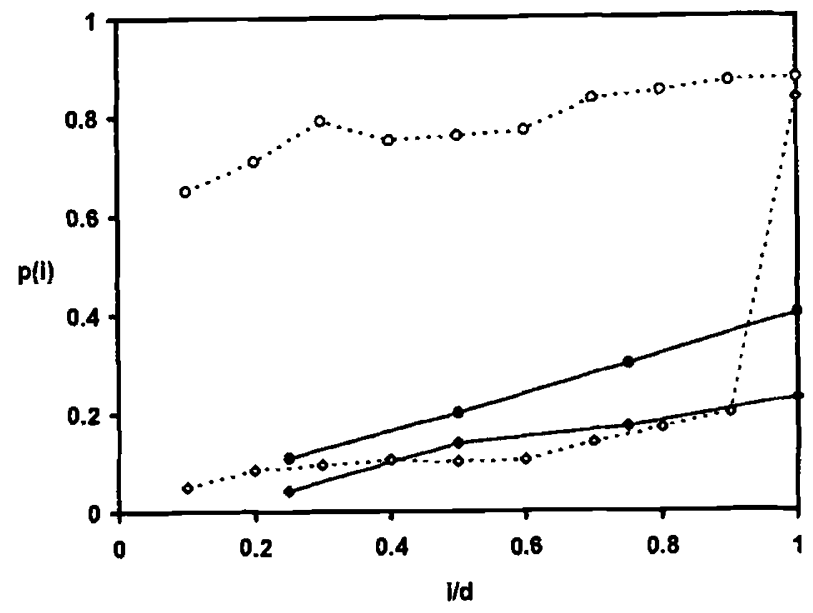

.. Slatkin's (1981) theoretical profile for a high gene flow species.

.....Slatkin's (1981) theoretical proflle for a low gene flow species.

-Maximum profile for striped bass gene flow.

$\rightarrow$ - Minimum profile for striped bass gene flow.

Fig. 3 Maximum and minimum qualitative estimates of gene flow for the striped bass. Profiles were obtained by plotting conditional-average RAPD marker frequencies $[p(i)]$ verses occupancy rate $(i / d)$. Theoretical profiles for high gene flow $\left(N_{\mathrm{e}} m=1.250\right)$ and low gene flow $\left(N_{\mathrm{e}} m=0.025\right)$ are after Slatkin (1981).

1969). Bandsharing-based similarity indices are higher for within-river system samples than for all comparisons between river systems (Table 4). This implies that individuals within each river system are genetically more similar to each other than to individuals from any other river system. Estimates of $F^{\prime}{ }_{\text {ST }}$ using these bandsharing similarity values indicate the presence of subdivision among river system samples $\left(F_{\mathrm{ST}}^{\prime}=0.44\right)$. Because subdivision was detected in the pooled Atlantic Coast samples, $F^{\prime}{ }_{\text {ST }}$ was computed stepwise between geographically proximate river systems and genetic subdivision was indicated in all comparisons (Table 4). Collectively, these data suggest that striped bass of the Hudson River, Delaware River, Chesapeake Bay, and Roanoke River systems are genetically differentiated from each other.

In general, results of both mitochondrial (Wirgin et al., 1990) and RAPD analyses are concordant in suggesting divergence among Atlantic Coast striped bass. However, the RAPD analysis suggests that genetic differentiation exists between Hudson River and Roanoke River striped bass $\left(F^{\prime}{ }_{S T}=0.46\right)$ that was not detected by previous mtDNA analysis (Wirgin et al., 1990). It is not unexpected that the RAPD analysis suggests divergence between these populations given that these two river systems are 
geographically the most distant from each other (Fig. 1).

Maximum and minimum estimates of gene flow based on analysis of conditional average marker frequencies (Slatkin, 1981) closely parallels the theoretical estimate for a 'high gene flow species' (Fig. 3). It is important to note that empirically based estimates of gene flow using this method on other marine species known to have pelagic larvae and potential for high gene flow have produced considerably higher profiles than Slatkin's (1981) theoretical estimate (Bohlmeyer \& Gold, 1991; McMillen-Jackson et al., 1994). Therefore the observed striped bass qualitative profile (Fig. 3) may be an indication of a moderate restriction in gene flow. Cluster analysis of both bandsharing- and frequency-based distances indicates that the sampled striped bass were not strongly differentiated, signalling that gene flow is likely among the samples (Fig. 2). Taken together, these data suggest that gene flow is occurring among the sampled Atlantic Coast striped bass populations.

The extent of genetic differentiation detected among the sampled striped bass is not in conflict with the levels of gene flow estimated between the samples. Theoretically, populations will be prevented from fixation of alternate neutral alleles via drift by as little as one effective migrant per generation (Spieth, 1974). Furthermore, significant divergence in allele frequencies can occur in a background of high gene flow (Wright, 1969; Allendorf \& Phelps, 1981). The sampled striped bass populations did not exhibit any fixed differences, but significant heterogeneity in marker frequencies was detected despite indications of the presence of gene flow. It appears that the barrier to gene flow resulting from the natal homing behaviour of migratory striped bass may be 'leaky' and does not provide complete isolation. Enough 'leakage' in gene flow is occurring to prevent fixation of alternate alleles, however it is not sufficient to prevent significant divergence in the frequencies of shared markers.

\section{Management implications}

Present estimates of gene flow suggest it may be inappropriate to assume that current levels of exchange between populations would be great enough to affect recruitment during a contemporary period of time. Given the longer time to sexual maturity of female striped bass (Setzler et al., 1980) and their numerically inferior numbers on the spawning grounds relative to males (Setzler et al., 1980; Chapman, 1990) recruitment will ultimately depend on female spawning activity. Whereas males may show less fidelity for natal reproduction (Chapman, 1987, 1989), the evidence suggests that females are strongly philopatric to their natal spawning sites (reviewed in Setzler et al., 1980; Chapman, 1990; Rago et al., 1992). Therefore the conservative approach to management of the migratory striped bass is to consider the sampled river systems as independent units.

Management of a mixed-stock fishery as a whole, essentially basing regulations on the numerically strongest stock, can result in excessive pressure and possible depletion of the weakest stocks (Pella \& Milner, 1987). Because all but one of the polymorphic RAPD markers were present in two or more samples, only 23 per cent of the combined sample of striped bass could be unambiguously classified into one of the four stocks. Using observed frequencies of shared mtDNA length variants, Wirgin et al. (1993) employed a generalized least squares approach to estimate the proportional contributions of Hudson River and Chesapeake Bay striped bass to the Atlantic mixed-stock fishery. A similar approach, employing observed RAPD marker frequencies, may allow estimation of the proportional compositions of all four striped bass populations to the Atlantic Coast fishery.

\section{Acknowledgements}

The authors thank K. A. Dunn, K. Noack and J. Remsen for their helpful discussions. We thank L. R. Richardson for sharing her expertise on the data analysis software used in this study. We thank E. A. Osterndorff for kindly providing the software used to construct similarity matrices. We thank R. W. Johnson and D. E. Axinn for their generous support of this research. We thank E. W. Radle, K. McKown, and B. Young (NY DEC); T. Baum and P. Himchak (NJ DFGW); D. Cosden (MD DNR); and $\mathrm{H}$. Johnson (NC DNR) for providing the samples of striped bass examined in this study. This work was supported in part by the Donald E. Axinn Fellowship for Ecology and Conservation Biology to J.P.B. and NIH Grant GM42563 to D.E.P.

\section{References}

ALLENDORF, F. W. AND PHELPS, S. R. 1981. Use of allelic frequencies to describe population structure. Can. J. Fish. Aquat. Sci., 38, 1507-1514.

BIELAWSKI, J. P., NOACK, K. AND PUMO, D. E. 1995. Reproducible amplification of RAPD markers from vertebrate DNA. Biotechniques, 18, 856-860. 
BOHLMEYER, D. A. AND GOLD, J. R. 1991. Genetic studies in marine fishes: II. A protein electrophoretic analysis of population structure in the red drum Sciaenops ocellatus. Mar. Biol., 108, 197-206.

Boreman, J. AND AUSTIN, H. M. 1985. Production and harvest of anadromous striped bass stocks along the Atlantic Coast. Trans. Am. Fish. Soc., 114, 3-7.

CHAPMAN, R. w. 1987. Changes in the population structure of male striped bass, Morone saxatilis, spawning in three areas of the Chesapeake Bay from 1984 to 1986. Fish. Bull., 85, 167-170.

CHAPMAN, R. W. 1989. Spatial and temporal variation of mitochondrial DNA haplotype frequencies in the striped bass (Morone saxatilis) 1982 year class. Copeia, 1989, 344-348.

CHAPMAN, R. w. 1990. Mitochondrial DNA analysis of striped bass populations in Chesapeake Bay. Copeia, 1990, 355-366.

Clark, A. G. AND LANigan, C. M. s. 1993. Prospects for estimating nucleotide divergence with RAPDs. Mol. Biol. Evol., 10, 1096-1111.

Koo, T. S. Y. 1970. The striped bass fisheries in the Atlantic states. Ches. Sci., 11, 73-93.

LYNCH, M. 1991. Analysis of population genetic structure by DNA fingerprinting. In: Burke, T., Dolf, G., Jefferys, A. and Wolf, R. (eds) DNA fingerprinting: Approaches and Applications, pp. 113-126. Birkhäuser Verlag, Basel.

MCMILLEN-JACKSON, A. L., BERT, T. M. AND STEELE, P. 1994. Population genetics of the blue crab Callinectes sapidus: modest population structuring in a background of high gene flow. Mar. Biol., 118, 53-65.

MERRIMAN, D. 1941. Studies of the striped bass (Roccus saxatilis) of the Atlantic Coast. U.S. Fish Wildl. Service Fishery Bull., 50, 1-77.

NEl, M. 1978. Estimation of average heterozygosity and genetic distance from a small number of individuals. Genetics, 89, 583-590.

NEI, M., STEPHENS, J. C. AND SAITOU, N. 1985. Methods for computing the standard errors of branching points in an evolutionary tree and their application to molecular data from humans and apes. Mol. Biol. Evol., 2, 66-85.

PARAN, 1., KESSELl, R. AND MICHELMORE, R. 1991. Identification of restriction fragment length polymorphism and random amplified polymorphic DNA markers linked to downey mildew resistance genes in lettuce, using near-isogenic lines. Genome, 34, 1021-1027.

PELlA, J. J. AND MILNER, G. B. 1987. Use of genetic markers in stock composition analysis. In: Ryman, N. and Utter, F. (eds) Population Genetics and Fisheries Management, pp. 247-276. University of Washington Press, Seattle, WA.

RAGO, P. J., DORAZIO, R. M., RICHARDS, R. A., DUEL, D. G.
AND Stephan, C. D. 1992. Emergency Striped Bass Research Study Report for 1990. U.S. Fish and Wildlife Service, National Marine Fisheries Service, and Atlantic States Marine Fisheries Commission, Washington, DC.

RICE, W. R. 1989. Analyzing tables of statistical tests. Evolution, 43, 223-225.

ROHLF, F. J. 1983. BıOM-PC: a package of statistical programs to accompany the text Biometry. W. H. Freeman \& Co., San Francisco, CA.

SAMBROOK, L., FRITSCH, E. F. AND MANIATIS, T. 1989. Molecular Cloning: A Laboratory Manual. Cold Spring Harbor Press, Cold Spring Harbor, NY.

SETZLER, E. M., BOYNTON, W. R., WOOD, K. V., ZION, H. H., LUBBERS, L., MOUNTFORD, N. K. ET AL. 1980. Synopsis of biological data on striped bass, Morone saxatilis (Walbaum). NOAA Technical Report, NMFS Circular 433.

SLATKIN, M. 1981. Estimating levels of gene flow in natural populations. Genetics, 95, 323-335.

SOKAL, R. R. AND ROHLF, F. J. 1969. Biometry: The Principles and Practice of Statistics in Biological Research. W. H. Freeman \& Co., San Francisco, CA.

SPIETH, P. T. 1974. Gene flow and genetic differentiation. Genetics, 78, 961-965.

SWOFFORD, D. L. AND SELANDER, R. B. 1981. BIOSYS-1: a FORTRAN program for the comprehensive analysis of electrophoretic data in population genetics and systematics. J. Hered., 72, 281-283.

WALDMAN, J. R. AND WIRGIN, 1. 1. 1993. Origin of the present Delaware River striped bass population as shown by analysis of mitochondrial DNA. Trans. Am. Fish. Soc., 121, 15-21.

WALDMAN, J. R., GROSSFIELD, J. AND WIRGIN, 1. 1. 1988. Review of stock discrimination techniques for striped bass. N. Am. J. Fish. Manag., 8, 410-425.

WILLIAMS, J. G. K., KUBELIK, A. R., LIVAK, K. J., RAFALSKI, J. A. AND TINGEY, s. v. 1990. DNA polymorphisms amplified by arbitrary primers are useful as genetic markers. Nucl. Acids Res., 18, 6531-6535.

WIRGIN, 1. 1., SILVERSTEIN, P. AND GROSSFIELD, J. 1990. Restriction endonuclease analysis of striped bass mitochondrial DNA: The Atlantic Coastal migratory stock. Am. Fish. Soc. Symp., 7, 474-491.

WIRGIN, 1. 1., MACEDA, L., WALDMAN, J. R. AND CRITTENDEN, R. N. 1993. Use of mitochondrial DNA polymorphisms to estimate the relative contributions of Hudson River and Chesapeake Bay striped bass stocks to the mixed fishery on the Atlantic Coast. Trans. Am. Fish. Soc., 121, 669-684.

WRIGHT, s. 1969. Evolution and the Genetics of Populations, vol. 2, The Theory of Gene Frequencies. University of Chicago Press, Chicago, IL. 